\title{
Critical Incident Assessment as a Tool to Reflect on Student's Emotional Response During International Experiences
}

\section{Mr. Matthew Korey, Purdue University}

Matthew Korey received his B.S. in Biomedical Engineering at Ohio State University (2011) where he studied the toxicity of various chemical compounds on hepatocytic cells. Matthew then joined the research groups of Dr. Jeffrey Youngblood and Dr. John Howarter at Purdue University in 2015 where he specialized in building a more robust understanding of sustainability in plastics through considering the full lifecycle of a product. For his work at Purdue, Matthew was awarded the NSF IGERT Fellowship (2016) and the NSF GRFP Fellowship (2017-2020). Matthew will receive his Ph.D. in Materials Engineering in May of 2020.

Caitlyn M Clarkson, Purdue University-Main Campus, West Lafayette (College of Engineering)

Caitlyn Clarkson is currently a Ph.D. candidate at Purdue University in Materials Engineering and will be graduating in May 2020. Her research is in polymer nanocomposite processing and characterization. She is a fellow in an NSF-funded integrative graduate education and research traineeship (IGERT) program.

Ms. Kali D Frost, Purdue University

Mr. Joseph Andler, Purdue University-Main Campus, West Lafayette (College of Engineering)

Joseph (Joe) Andler is a Ph.D. candidate in materials engineering at Purdue University. Here, he is coadvised by Drs. Carol Handwerker in Materials Engineering and Rakesh Agrawal in the Davidson School of Chemical Engineering. His research has a dual focus of 1. developing novel chalcogenide semiconductors for application in solution-processed photovoltaics and 2. completing environmental analyses including life cycle assessments and leaching procedures on these novel systems to identify areas of improvement in the context of environmental performance. Joe was a Ross fellow upon entering Purdue and later became an Integrative Graduate Education and Research Traineeship (IGERT) fellow supported by the National Science Foundation. He received his B.S. in physics from Marietta College in 2015.

\section{Congying Wang, Purdue University-Main Campus, West Lafayette (College of Engineering)}

Congying Wang is a doctoral candidate in the School of Materials Engineering at Purdue University. Her research interests include the applications of environmental-friendly lead-free Sn coatings in electronics, the recycling of electronic wastes as part of the circular economy, and the design of interdisciplinary and intercultural curricula, particularly on global sustainability.

\section{Dr. Melissa S Reeves, Department of Chemistry, Tuskegee University}

Melissa S. Reeves received her B.S. in chemistry at University of Florida and her Ph.D. in chemistry at Indiana University at Bloomington. She is an associate professor of chemistry at Tuskegee University where she specializes in physical chemistry and computational chemistry. Her research interests have ranged from calculating transition states of small molecule reactions in solution to molecular dynamics of polymers. She has worked on two American Chemical Society Physical Chemistry Exam Committees and is an active participant in the Process Oriented Guided Inquiry Learning Physical Chemistry Laboratory (POGIL-PCL) community.

\section{Carol A Handwerker}

Carol Handwerker is the Reinhardt Schuhmann, Jr. Professor of Materials Engineering at Purdue University. 


\title{
Critical incident assessment as a tool to reflect on students' emotional response during international experiences
}

\begin{abstract}
International experience was an essential component of the Integrative Graduate Education and Research Traineeship (IGERT)-Sustainable Electronics (SE) Program between Purdue University and Tuskegee University as electronics manufacturing and recycling primarily occur abroad in India, many countries in Africa, and China. During this two-year IGERT-SE program, students visited Delhi and Rajasthan, India to meet with representatives throughout the supply chain including mining and extraction experts, electronics manufacturers, electronics assemblers, non-government organizations, recyclers and waste handlers, and many other subject matter experts. The purpose of the trip was to obtain hands-on, in-person experience visually inspecting and participating in all levels of the electronics lifecycle. Additionally, the students were tasked with learning about sustainable practices from the local experts working in the field and reflecting on areas for improvement. It is well known that traveling abroad immerses students, sometimes for the first time, in an unfamiliar culture and that their emotional response to experiences affects how they perceive the cultural and professional practices of the people and places they visit. To help students process their experiences, the IGERT-SE Program adopted the critical incident assessment (CIA) framework. The CIA was modified for the sustainability in electronics focus of the program in order to best help students understand how their emotional response affects their perception of practices pertaining to sustainability. While literature has shown the effectiveness of this assessment tool in many contexts (e.g. study abroad programs, social work, etc.), to the best of our knowledge, no one has utilized this technique as a method for individuals to assess sustainability in an international culture and framework.

The following study analyzes the use of critical incident assessment (CIA) to improve understanding of the complex interactions between environmental, economic, and social/sociopolitical factors during focused educational trips to unfamiliar cultures and workplaces, and the interactions that took place within them as part of the international experience component of the NSF IGERT-SE Program. Results were collected from the students and faculty via a survey to identify factors and practices which were essential to the implementation of this tool in an interdisciplinary setting abroad. The survey was structured using a mixture of matrix questions, Likert scale questions, ranking questions, and open-ended questions. Questions covered topics such as environmental factors (e.g. time of day and location), group dynamics (e.g. group size and demographics) and level of familiarity with the tool. From the responses obtained, best practices are proposed to help enable future educators to utilize the CIA in a maximally impactful manner. Within this work, the authors will explore the usefulness of this tool as a metric to assess the sustainability of the electronics lifecycle in an International setting.
\end{abstract}




\section{Introduction}

In a global society, cultural competence - or the ability to work with, learn from, and interact with people from belief systems and cultures other than one's own [1] - is a necessity. This is as true for engineering as it is for many other disciplines. The 'critical incident technique' (CIT), also called the critical incident approach or assessment (CIA), has been used as a developmental tool to build cultural competence and knowledge when students are immersed in a foreign culture. [2] This work will discuss the experiences and use of the CIA by an interdisciplinary, multicultural group of graduate students brought together by the National Science Foundation (NSF)-funded Integrative Graduate Education and Research Traineeship (IGERT) program "Global Traineeship in Sustainable Electronics." During its tenure, three cohorts comprised of students from Purdue University and Tuskegee University participated in the program. An integral part of this two-year traineeship was an international trip to India. This visit was designed to promote several of the program's objectives: 1) developing systems thinking and interdisciplinary collaboration relative to sustainability and global supply chains, 2) encouraging leadership in cross-cultural teams, and 3) help students recognize barriers while building bridges. The CIA was initially introduced as a tool to help students reflect on their experiences abroad while providing a safe and supportive environment for learning under the guidance of experts in sustainability and electronics manufacturing.

While the international trip was expected to be immensely valuable for students, it was anticipated that the students, who were from a variety of educational, personal, and cultural backgrounds, would likely not have experienced traveling abroad, especially for academic purposes. Additionally, while the students could witness the entire lifecycle of an electronic device in India, it is also a country with remarkably different cultures than the USA surrounding sustainability and worker safety. Introducing graduate students to international cultures can introduce significant emotional impact, or culture shock, which could result in biased analysis of situations and thus a biased determination of whether a practice was sustainable or not. [3, 4] Therefore, the CIA was reframed in the context of sustainability to help students focus on the reason for their visit as well as to build cultural competence in professional and societal practices internationally.

This study aims to understand whether the CIA framework was able to enhance personal and group intercultural development in the context of sustainability through use of reflection and discussion. With the motivation to strengthen this development most effectively, this study investigates the strengths and limitations of the CIA tool used to identify bias, understand intercultural sustainability, and generate cultural awareness. This study also provides insight into group and environmental attributes that may be conducive to successful application of this tool. Surveying of CIA users was completed using a mixture of matrix questions, Likert scale questions, ranking questions, and open-ended questions that covered topics such as environmental factors (e.g. time of day and location), group dynamics (e.g. group size and 
demographics) and level of familiarity with the tool. It is the hope of the authors that this work will help future students and faculty better understand the deeply complex, intersectional topics within sustainability when viewed within an international, cultural context.

\section{Relevant Literature Review and Background}

Flanagan introduced the "critical incident technique" (CIT) in 1954 as a systematic way to record observations about a critical incident in an objective manner for use in practical problem solving. [5] Fitzgerald defines a critical incident as "...distinct occurrences or events which involve two or more people; they are neither inherently negative nor positive, they are merely distinct occurrences or events which require some attention, action or explanation; they are situations for which there is a need to attach meaning". [6] Over the subsequent decades, the CIT (or CIA) has been adapted for many purposes, including cultural competence training and group critical incident stress debriefing.

McAllister et al (2006) described the need for development of an intercultural skill set as a requisite for professional competence. [2] Universities play an important role in developing cultural knowledge and competencies in their students [2] which is reflected in the ABET engineering accreditation requirements for student outcomes (Criterion 3, Outcome 4). [7] Experiential education (e.g. a study abroad program) can be an effective method for developing these skills, but 'requires reflection and critical analysis' in order to transform experience into knowledge. [8] This concept is supported by Sieck et al, who found that critical reflection, such as the activities encouraged by CIT, is aligned with the metacognitive strategies that were commonly displayed by cross-cultural experts. [9] Further, Lutterman-Aguilar and Gingerich contend that critical analysis and reflection are a collective process and dialogue with others is key to helping students 'move beyond their own perspectives to new understandings.' [8]

Cultural bias is "the tendency to interpret and judge phenomena in terms of the distinctive values, beliefs, and other characteristics of the society or community to which one belongs". [1] Understanding one's own biases and prejudices can help one develop skills to enhance interactions and engagement with individuals from another culture. Biases begin from our personal backgrounds, e.g. experience and information that we gather early in life and are made more complex because they intersect with our culture and identity. Critical reflection allows us to identify and acknowledge both explicit and implicit (unknown or hidden) bias, [10] and is an important step in becoming more culturally competent. $[2,11]$

Cultural competence may be especially important for training students in global electronics sustainability due to the global nature of the electronics supply chain and associated waste (ewaste). Illegal, transboundary shipments of e-waste, unfair labor practices, mineral extraction practices which fuel conflict, and other environmental and social issues associated with the electronics industry are complex and require international and cross-cultural solutions. Broadly, the UN Organization for Economic Co-operation and Development conducted a global 
assessment to measure young people's cultural competence, as they consider globally competent knowledge, skills, attitudes and values as vital for promoting 'sustainable development and collective well-being.' [12]

In addition to developing cultural competence, the critical reflection required by the CIA can act as a debriefing tool for critical incidents that may cause stress or anxiety for participants. [13] Critical Incident Stress Debriefing (CISD) is a common practice for emergency personnel (e.g. police, firefighters, nurses) to deal with stress after a traumatic event; [13] however, it has also been adapted for other settings, including study abroad programs, where it acts as an "emotional first-aid." [14] One of the main purposes of a CISD is to mitigate the impact of a critical incident through timely discussion and reflection upon the incident. While the primary intent of the CIA in the context of the IGERT program was to build cultural competence through reflective critical thinking, the tool supported the building of trust, respect and understanding among the group, which is often the result of peer-supported CISD. [15]

\section{Background Information on Sustainability CIA}

CIA-Sustainability Framework: Within the IGERT program, this technique was adopted in order to help the students understand the complex, intersectional challenges associated with the electronics life cycle during their trip abroad to India. The structure of the CIA that was utilized for this can be found in the Supplemental Information to this document. They include: Section 1) Account of the Incident, 2) Initial Responses to the Incident, 3) Issues and Dilemmas Highlighted by the Incident, 4) Learning, 5) Outcomes. The goals of the sections are explained in further detail (Figure 1). As discussed earlier, the purpose of the structure of the CIA was to enable students to understand the complex cultures and challenges in which they were immersed to better understand the sustainable (or unsustainable) practices they were witnessing. Walking students through the account, their response, learning opportunities, and outcomes was designed to purposefully enable this process to take place, while additionally fostering structured discussion within the group. 
Section 1:

Account of the

Incident

Section 2:

Initial Responses to

the Incident

Section 3:

Issues and Dilemmas

Highlighted by the

Incident

Section 4:

Learning

Section 5:

Outcomes
In this section, students discussed the critical incident in further detail by closely analyzing its participants, locations, and context. Regarding their role and involvement in the incident, many students often reported feeling like "observers" or "witnesses" to the incidents instead of active participants. Although not always true, this sentiment persisted throughout the intercultural experience.

Here, students were asked to identify and articulate their own responses, emotions, thoughts, and feelings at the time of the incident. Additionally, it was helpful to have them identify other participants' perspectives to gain a deeper understanding of different viewpoints. Students often shared their belief regarding the possible mindset of other individuals when these participants were not available for the analysis.

Highlighting issues and dilemmas in the context of the trip goals allowed students to use their experiences to identify possible interdisciplinary collaborations. For this trip, the underlying goal of understanding electronics sustainability in a global context allowed students to use their knowledge and perspectives to brainstorm innovative solutions to problems that were identified by the group.

This section was important for identifying and articulating specific learning points that can be referenced when identifying and overcoming biases. Students were asked to identify what they had learned about themselves, their relationships with others, and what policies and procedures they might be able to influence. This section also has students identify what new knowledge may be helpful for further developing an explanation of the incident.

The purpose of this section was to motivate introspection about how this event has impacted students' perspectives. Here, students articulate any change the incident has made to their practice of improving electronics sustainability or how they may think, feel, or act differently in future situations. Lastly, students are asked to share new perspectives and thoughts about the incident relative to the feelings they had during the incident.

Figure 1. Framework for the CIA used by the IGERT- "Global Traineeship in Sustainable Electronics" program.

Logistics: During the international trip students performed a CIA daily. CIAs were performed in a group, with group sizes between 7 and 20 people depending on the cohort. CIAs were performed in a variety of places including hotel lobbies or patios, as well as while riding on buses from site to site. Group discussions took place in one of two arrangements: sitting in a circle when space was available or in rows (when conducted on the bus). On at least one occasion, two groups were formed to conduct the CIA as the group had to travel on two separate buses. Depending on the group's travel schedule, CIAs were conducted from early morning (a rare occurrence) to late evening. Depending on the location, the background noise level could be quite loud or very quiet.

Running the CIA: Some cohorts adopted an organizational structure for the CIA, in which a volunteer leader would mediate the discussion and a volunteer note taker would record responses. Some cohorts also elected to have time-limits on the discussion time. In that case, an optional role of a timer- a person to keep track of the time and set the pace- was also elected. The roles rotated each day to share the responsibility. Group discussions were student-led and professors, although present, rarely participated unless to address a technical question or provide cultural context if they felt comfortable. 


\section{Methods}

A Qualtrics survey was developed to collect students' opinions and feedback about the use of the CIA-sustainability framework. Survey questions consisted of matrix questions, Likert scale questions, ranking questions, and open-ended response questions which can be found in the supplemental information. Student responses were normalized by the total number of responses per question to obtain percentages of each response. For scaled agree/disagree-style questions (e.g. Question 1) students who answered somewhat or strongly agree were summed to be the "agree" category for analysis, whereas all other answers were organized into the "did not agree" category. Additionally, the median and mode for each answer are reported, as they have been found to better show trends in the data for Likert-style questions than the mean. [16] Chisquared analysis was used to determine statistical differences in Likert questions, with "agree" and "not agree" used as the variables of interest. Extended responses were used to clarify trends and provide context.

Students from all three IGERT cohorts were polled. Of the 28 students who were associated with the program, between 13-15 responded (46-53\% response rate) as 2 users began but did not complete the survey. Chi-square analysis was run in Microsoft Excel and the results are reported in the document. Ranking-type questions were analyzed by assigning a ranking of 1 for a time with 4 points, ranking of 2 with 3 points, etc. and summing up the scores for each time of day.

\section{Results \& Discussion:}

\section{Understanding International Sustainability}

The CIA was introduced to help students process/assess their experiences during the industrial visits, like those in the United States and in India, where students interfaced with various stakeholders in electronics manufacturing. The majority of students felt that their previous IGERT education affected their perception of both environmental and social sustainability internationally $(93.3 \%)$ and that the CIA helped them understand the sustainability or sustainable practices of the places and organizations they visited (100\%) while creating a space for them to share their thoughts and feelings $(100 \%)$, listen to their peers (100\%), and ask additional questions $(100 \%)$.

During a visit, students typically met with various representatives of the company and toured the location in which they might learn about processes, how the company functions, and the corporate responsibility initiatives of the company, including efforts to make the systems within the company and within communities more sustainable. Having been taught primarily North American standards and practices of sustainability in the classroom, students may enter industrial settings with preconceived notions of what sustainability should be or looks like in industry practices, government involvement, etc. When asked whether they found any practices in India to be more or less sustainable when viewed through the lens of a North American measure of 
sustainability, all students agreed that they did (100\%). Having previous knowledge of companies in the USA provided a point of reference for many students as did their personal experience which came up in their comments. Several students commented that while many facilities were up to USA standards taught in the classroom, others were not and, in those cases, cited specific violations such as the "disregard for employee health and safety at the lead acid battery factory," and "smell of chemicals...that signified the lack of health regulations and PPE required in comparison to the USA." At one of the companies, students were presented with the idea that waste materials (a phenolic resin used in manufacturing electronic components) could be used to produce bricks. These bricks were given away to whoever picked them up off the street. By the company, it was presented as more sustainable because it allows the waste to be repurposed and the building materials are free (therefore would go to low income people that build their houses incrementally over time). Two students expressed concern about this practice, because while it appears more sustainable on the surface, there could be safety concerns with using these materials which may or may not be covered by environmental and OSHA-type regulations for human and environmental exposure.[1] However, while the students noted differences in worker safety cultures, students also identified more socially sustainable practices in India such as the practice of "promoting from within the company- rather than external hiringwhich makes retention higher and employees more motivated," which was a common culture among many companies toured in India.

Students overwhelmingly agreed that the CIA helped them reflect deeply on at least one critical incident (78\%), identify incidents where the group had conflicting perceptions (100\%), and on at least one occasion, changed their understanding of an incident (92.2\%). All of these factors could be responsible for the ability of students to understand the complex dynamics of the incidents described in the responses to the survey. Students additionally identified that the CIA enabled them to ask questions and get clarification about critical incidents (100\%), made them aware of critical incidents they may not have noticed (100\%), and encouraged further discussion after the CIA was over (92.2\%).

\section{Identification of Personal Bias \& Enhancing Cultural Competence}

Assessing sustainability practices abroad necessitates a level of cultural competence in which acknowledgement and understanding of one's own personal biases are key. Students were polled to ask whether they felt the CIA was a tool that enabled them to identify their personal biases (Fig. 2). Students largely felt that the CIA enabled them to identify their personal biases (80\%) and believed that these biases provided unique perspectives during the discussion (73.3\%). Students additionally identified that their personal biases affected their perception of at least one critical incident (73.3\%), and cited on more than one occasion an experience during their time visiting a site where women were employed to sort and categorize solid waste for composting. One student remarked that they were shocked to see women employed to 'sort trash'. This was especially remarkable to the student because the women worked in conditions that were visibly 
unclean and with little protective clothing, while their male supervisors seemed to be "sitting around". The student was initially quite upset by the scene, but by critically reflecting on the incident through CIA, realized that they were imposing their own ideas of family and workplace culture. After discussing the incident with the group, the student realized that these working conditions were vastly preferred to what the women were previously doing and this job, in contrast, was providing steady work and education for their children. The student concluded that the incident was far more complex than they initially thought and had to be considered within the context of both Indian culture and cross-cultural concepts of sustainability. This example indicates quite clearly the transition in thinking for the student made possible by the CIA and that through fostering discussion it could increase their cultural competence through identifying their personal biases. This result is consistent with other responses which indicated that students felt the CIA was a useful tool for increasing their cultural awareness (92.33\%).

Respondents were unclear as to whether their responses to critical incidents affected their ability to analyze the situation from an unbiased perspective (53.4\% Agree, Mode: Neutral). These results indicate that students had an initial perception of what was happening in the moment they were seeing it, but upon reflection were not necessarily biased in their analysis of what happened - as evidenced by the incidents involving the phenolic bricks, safety concerns, and social responsibility. This result is perhaps a product of the group being observers for most critical incidents, but is likely also a product of the use of the CIA as indicated by survey responses. This could explain other results which showed that respondents felt the CIA was a more useful tool for increasing their cultural awareness than they had originally anticipated $\left(\chi^{2}=8.33, \mathrm{df}=1\right.$, $\mathrm{p}=0.004)$.

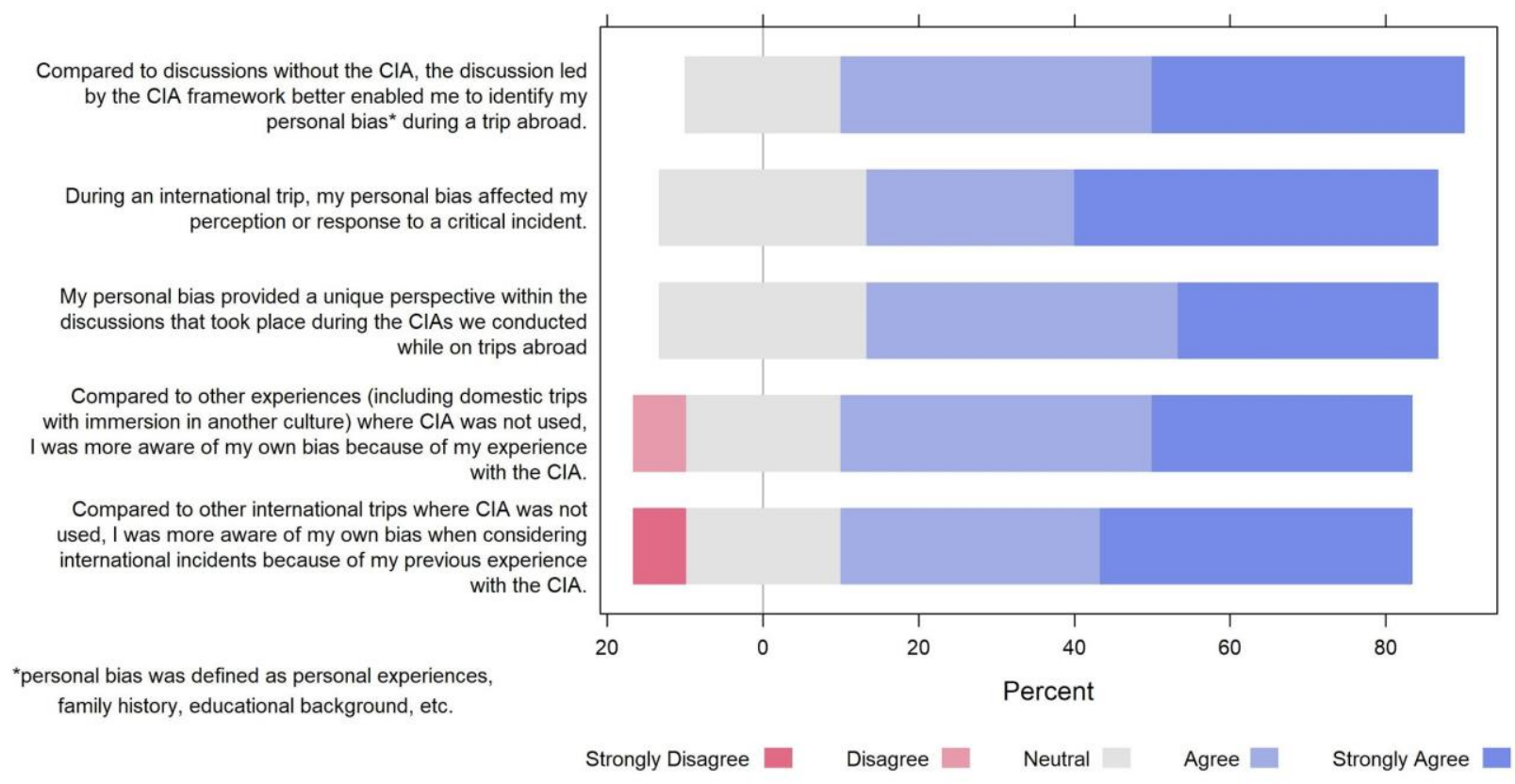

Figure 2. Student responses pertaining to personal bias. 
The CIA was not only a tool useful for identifying personal bias during the trips in which the CIA was practiced, but it also made students more aware of their biases on future experiences. Students identified that the use of the CIA during one international trip made them more aware of their own biases on other international trips (73.3\%) and domestic trips (73.3\%) where they did not use the CIA. Respondents additionally indicated long-term impacts of the CIA when they indicated that, "frameworks such as this one (have) assisted me during my transition/tenure to/in industry," and by indicating they discussed these ideas with their friends outside of the program. These results indicated that students felt much more long-term effects from the use of the CIA in this program, which was reinforced by the repeated use of the CIA every day during the two-week experience in India.

\section{Group Dynamics}

Students were asked to help determine whether the CIA affected group dynamics and thereby enhanced discussion on critical incidents (Fig. 3). Students felt that the CIA allowed them to listen to their peers' feelings/thoughts about a critical incident (100\%), express their own feelings about a critical incident (92.3\%), and develop trust in the other students during the trip (68.5\%). Students may have been more willing to share their feelings with each other because they trusted each other. However, poor group dynamics can potentially serve as a barrier to communication, which was observed in at least one IGERT cohort. From follow-up discussions, it was determined that students with strong opinions and personalities can potentially create an unproductive CIA environment. This idea was supported by further explanations from respondents who indicated, "The framework was useful to foster discussion, but its usefulness was partially limited by the willingness of others to engage." 


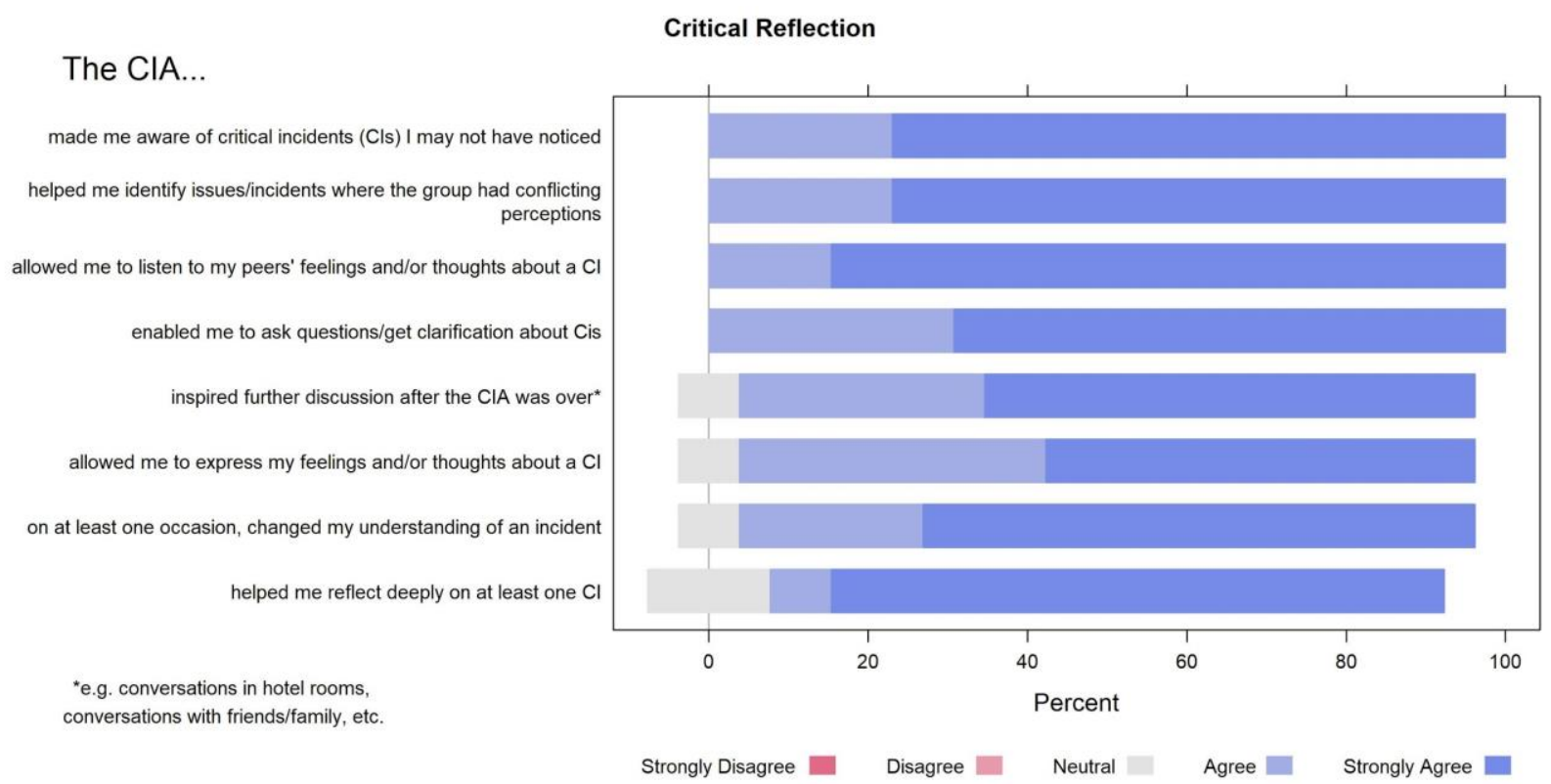

Figure 3: Student responses pertaining to the use of the CIA to facilitate discussion and its impact on group interactions.

Changes in dynamics between cohorts affected the effectiveness of the CIA, as reported by followup interviews. Interview respondents indicated that groups who were more interested in learning from others from the visited area tended to more positively utilize the CIA. Additionally, while the respondents from this study indicate that they felt that the CIA helped them develop trust, there were other opportunities within the program to develop trust. This included once-per-semester inperson meetings and informal gatherings including dinner at restaurants, homes of faculty and homes of students in the program. Students indicated that the CIA was an important aspect to this trust development.

When performing CIAs, students felt their critical incident was chosen about half of the time or slightly less. However, students did not feel that the critical incident they suggested was less important when the group chose to analyze a different critical incident (69.2\%). This could have been because students often only identified a few (1-3) critical incidents per day and perhaps felt they were equally important but only one needed further discussion/clarification from the group. While students reported that they were comfortable sharing their ideas and thoughts with the group (84.6\%), they did not necessarily feel they contributed equally to their peers $(53.1 \%$ Agreed, Mode: Neutral). This could be because students did not feel equipped to discuss the complex cultural aspects of the events which took place, and instead relied on their peers and faculty to provide this perspective or perhaps other participants talked too much. Students felt significantly more interested in participating in the CIA when the group had different thoughts about an incident $(92.3 \%)$ than when the group had the same thoughts about an incident $(46.1 \%)\left(\chi^{2}=6.5, \mathrm{df}=1\right.$, $\mathrm{p}=0.01$ ) (Fig. 4). When the group largely agreed, students may have felt other people were saying what they thought and didn't need to participate to make sure their voices were heard. Another 
explanation could be that students felt the CIA became more of an exercise when students agreed rather than an opportunity for personal growth when they disagreed. Regardless, it might suggest the importance of having a diverse group of people who have differing opinions, personal experiences, etc. to contribute to the conversation.

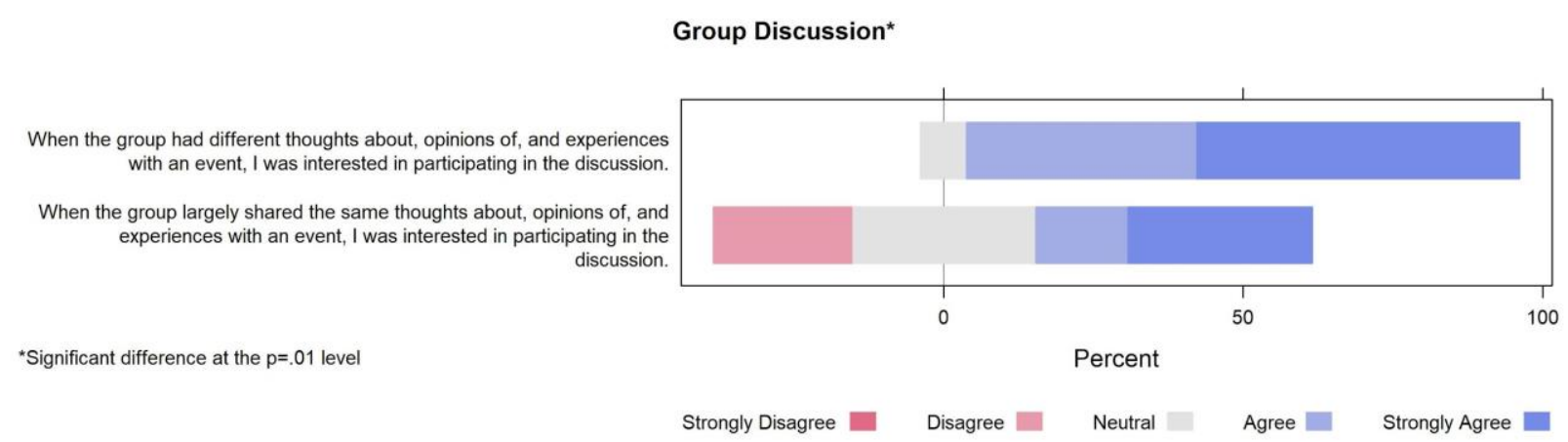

Figure 4. Student responses on their willingness to participate when students shared opinions versus when they did not.

When polled, respondents indicated that they felt the CIA was a useful tool for enhancing group discussions (100\% Agreed). Respondents felt, in retrospect, that the CIA was more useful as a tool for supporting group discussions than they originally anticipated when it was first introduced (69.4\% Agreed) $\left(\chi^{2}=6.19, \mathrm{df}=1, \mathrm{p}=0.01\right)$. It is suggested that the CIA's ability to help students listen and express their feelings and develop trust at least played a part in the ability for the tool to enhance discussion.

\section{Environment}

Students were polled about the ideal environment in which to perform the CIA. Students were asked about the ideal group size, time to completion, lighting in the room, how the chairs were arranged, and other factors. The respondents for this survey indicated ideal CIA environment is a group of 5-10 people (69.2\%), is 31-60 minutes long (84.6\%) and takes place in the afternoon (Score: 42). Morning (50\%) and late night CIAs (50\%) were the only options listed as a last choices indicating that these were not preferred times by many of the respondents. Most CIAs fell within the 30-90 minute timeframe on average, as suggested by follow-up interviews with respondents. This indicates that if students would prefer to have a CIA in less than 60 minutes they should use some method to limit the time of discussion. Additionally, as respondents indicated that the CIA inspired further conversation after the CIA was complete, it is important to remember that the CIA may not be fully resolved in the time limit. Encouraging students to continue conversations after the CIA could potentially be beneficial for their personal development. 
Respondents indicated that the space affected their willingness to participate in the CIA (69.2\%) and that the students should be situated in a circle (91.7\%). Students, surprisingly, indicated that the room does not need to be well-lit (76.9\%). This could be explained by the use of tablets with back-lit screens when filling out the CIA which could be used in the dark. However, as many CIAs were performed on buses and moving vehicles, it is suggested that students find a way to situate themselves in a circle in whatever space they occupy. Follow-up interviews suggested that students who did not wish to participate in a CIA could more easily avoid engaging when not in a circle, but could not avoid participating as easily when situated in a circle.

While a majority of respondents indicated they get motion sickness when writing in a moving vehicle, only $40 \%$ of them indicated that it affected their participation in the CIA. This result could possibly be explained by the fact that only one student needed to serve as the scribe, and students could participate in the CIA without serving in that role. Additionally, students on the trips were aware of who was motion sick and would often volunteer to scribe in their place. That being said, the roads on many international trips were bumpy resulting in some students getting motion sickness regardless, which could explain the $40 \%$ of cases where students got motion sick.

Most students (69\%) felt uncomfortable conducting the CIA where people could overhear and that the level of background noise affected their participation (53.9\%). On at least one occasion the bus driver overhearing a conversation during the trip made respondents uncomfortable, as the students noticed the driver silently reacting to what was said. However, students were more comfortable when faculty, who did not always participate, were present in the group (61.6\%). These results suggest the discomfort students observed was particularly with regard to people listening that did not know the context of the conversation. Performing the CIA in a private space where others could not overhear the conversation or providing context to the conversation to the people who could overhear the conversation (e.g., bus drivers or tour guides) when that is unavoidable, may help prevent this. It is encouraged to include tour guides and bus drivers to participate in the CIA when they would like to, even though this practice was not implemented during this trip.

\section{Best Practices Summary}

Over the course of seven years, the CIA was used by the Global Electronics Sustainability IGERT program. Our best practices for creating an environment for participating in the CIA, based on student survey feedback, are shown in Table 1. 
Table 1. Best practices based on student feedback.

\begin{tabular}{|c|c|}
\hline Size of Group & $5-10$ people \\
\hline Time to Complete CIA & $30-60$ minutes \\
\hline Time of Day & Afternoon \\
\hline Type of Space & Private \& Quiet \\
\hline Arrangement of Students & Circular (Facing Each Other) \\
\hline
\end{tabular}

\section{Conclusions}

The CIA framework was adapted for the purpose of helping graduate students better understand sustainability internationally and increase their cultural competence- skills essential to their future success and in line with the goals of the NSF IGERT- "Global Traineeship in Sustainable Electronics" program. Responses suggest that the CIA was a useful tool for identifying personal biases, increasing cultural competence, enhancing group discussions, and understanding sustainability in an international context. Group dynamics were critical to the success of the CIA, with a willingness to participate being of paramount importance. Best practices for the environment, time, and group structure were ascertained from respondents to this study. It is the hope of the authors of this work that future educators who wish to adopt this tool into their programs can do so with these best practices in mind to ensure the CIA is maximally impactful.

\section{Acknowledgements}

The authors would like to thank Dr. Philip Sanger for his encouragement to share our experiences and his advice on topics to write about, Dr. Kory Cooper for his conversions about our program and help in finding literature resources, and Dr. Gamini Mendis who was instrumental in developing an outline for this work.

Researchers were supported in this work through the National Science Foundation-Integrative Graduate Education and Research Traineeship: Sustainable Electronics Grant (Grant Number 1144843) and the National Science Foundation Graduate Research Fellowship under Grant Number DGE-1333468.

\section{Bibliography}

[1] American Psychological Association. "APA Dictionary of Psychology: Cultural Bias." (accessed 2020).

[2] L. McAllister, G. Whiteford, B. Hill, N. Thomas, and M. Fitzgerald, "Reflection in intercultural learning: examining the international experience through a critical incident 
approach," Reflective Practice, vol. 7, no. 3, pp. 367-381, 2006, doi:

10.1080/14623940600837624.

[3] H. C. Triandis, Theoretical concepts that are applicable to the analysis of ethnocentrism. Applied cross-cultural psychology.

[4] R. F. Chapdelaine and L. R. Alexitch, "Social Skills Difficulty: Model of Culture Shock

for International Graduate Students," Journal of College Student Development, vol. 45, no. 2, p. 167, 2004, doi: 10.1353/csd.2004.0021.

[5] J. C. Flanagan, "The critical incident technique," Psychological Bulletin, vol. 51, no. 4, pp. 327-358, 1954, doi: 10.1037/h0061470.

[6] M. Fitzgerald, J. Kingsley, Ed. Establishing cultural competency for health professionals (Anthropological approaches to psychological medicine.). London, 2000.

[7] ABET, "Criteria for Accrediting Engineering Programs, 2019 - 2020," 2019.

[8] A. Lutterman-Aguilar and O. Gingerich, "Experiential pedagogy for study abroad:

educating for global citizenship," Frontiers: The Interdisciplinary Journal of Study Abroad, vol. 8, pp. 41-82, 2015.

[9] W. R. Sieck, J. L. Smith, and L. J. Rasmussen, "Metacognitive Strategies for Making Sense of Cross-Cultural Encounters," Journal of Cross-Cultural Psychology, vol. 44, no. 6, pp. 1007-1023, 2013, doi: 10.1177/0022022113492890.

[10] C. Motzkus et al., "Pre-clinical medical student reflections on implicit bias: Implications for learning and teaching," PLoS ONE, vol. 14, no. 11, 2019, doi:

10.1371/journal.pone.0225058.

[11] A. Blanchet Garneau, "Critical Reflection in Cultural Competence Development: A Framework for Undergraduate Nursing Education," The Journal of nursing education, vol. 55, no. 3, p. 125, 2016, doi: 10.3928/01484834-20160216-02.

[12] Development Organization for Economic Cooperation, "Preparing Our Youth for an Inclusive and Sustainable World: The OECD PISA Global Competence Framework," ed: OECD Publishing, 2018.

[13] J. T. Mitchell, "When disaster strikes... The critical incident stress debriefing process," Journal of Emergency Medical Services: JEMS, vol. 8, no. 1, pp. 36-39, 1983.

[14] International Sustainable Development Studies Institute. "Emotional First Aid (EFA) Course." (accessed 2020).

[15] National Office of Fire and Aviation, "Critical Incident Stress Management: What to Expect," 2020.

[16] A. Joshi, S. Kale, S. Chandel, and D. K. Pal, "Likert Scale: Explored and Explained," British Journal of Applied Science \& Technology, vol. 7, no. 4, pp. 397-403, 2015. 


\section{Supplemental Information}

\begin{tabular}{|l|l|}
\hline $\begin{array}{l}\text { Account of the Incident } \\
\text { who was involved? }\end{array}$ & Your Notes \\
What was the purpose of your & \\
role/involvement in the incident & What was the context of this incident \\
$-\quad$ e.g. previous involvement of yourself or & \\
others with those involved or not? & \\
\hline $\begin{array}{l}\text { Initial Responses to the Incident } \\
\text { What were your thoughts? }\end{array}$ & \\
What were your feelings/emotions at \\
the time of this incident? \\
What were the responses of other \\
key individuals to this incident? If not \\
known, what do you think these might have \\
been?
\end{tabular}


Issues And Dilemmas Highlighted By

This Incident

What practice dilemmas for sustainable electronics were identified as a result of this incident?

What are the values and ethical

issues which are highlighted by this incident?

Are there implications for interdisciplinary and/or collaborations

which you have identified as a result of this incident? 


\section{Learning}

What have you learned about

a) yourself

b) relationships with others

c) the task of improving the

sustainability of electronics, organizational policies and

procedure you can influence

What theory or knowledge has helped you or might have helped you develop a better understanding about some aspect of this incident?

What research has (or might have) helped your understanding about some aspect of this incident?

What intervention or communication skills might you use to develop some understanding about this incident and how the situation might be changed?

How might an understanding of the legislative, organizational, and policy context explain some aspects associated with this incident?

What future learning needs have you identified as a result of this incident? How might this be achieved? 


\section{Outcomes}

What difference will it/has it made to your practice of improving sustainability of electronics?

What impact has your involvement in this situation had on possible outcomes for the future?

Are there ways in which this incident has led (or might lead to) changed in how you think, feel, or act in particular situations?

- What are your thoughts and feelings now about this incident?

Figure S1: The CIA Framework (adapted from https://www.bradford.gov.uk/.../CriticalIncidentAnalysisFrame January 2015) 
Table S1: Results from Qualtrics Survey

\begin{tabular}{|c|c|c|c|c|c|c|c|}
\hline Question Text & $\begin{array}{c}\text { Strongly } \\
\text { Agree }\end{array}$ & $\begin{array}{c}\text { Somewha } \\
\text { t Agree }\end{array}$ & Neutral & $\begin{array}{l}\text { Somewha } \\
\text { t Disagree }\end{array}$ & $\begin{array}{l}\text { Strongly } \\
\text { Disagree }\end{array}$ & Median & Mode \\
\hline \multirow{2}{*}{$\begin{array}{l}\text { My personal bias (personal experiences, family } \\
\text { history, educational background, etc.) provided a } \\
\text { unique perspective within the discussions that } \\
\text { took place during the Critical Incident } \\
\text { Assessments (CIAs) we conducted while on } \\
\text { trips abroad. }\end{array}$} & $33.30 \%$ & $40.00 \%$ & $26.70 \%$ & $0.00 \%$ & $0.00 \%$ & \multirow[b]{2}{*}{$\begin{array}{c}\text { Somewhat } \\
\text { Agree }\end{array}$} & \multirow[b]{2}{*}{$\begin{array}{c}\text { Somewhat } \\
\text { Agree }\end{array}$} \\
\hline & 5 & 6 & 4 & 0 & 0 & & \\
\hline \multirow{2}{*}{$\begin{array}{l}\text { During an international trip, my personal bias } \\
\text { (personal experiences, family history, } \\
\text { educational background, etc.) affected my } \\
\text { perception or response to a critical incident. }\end{array}$} & $46.70 \%$ & $26.70 \%$ & $26.70 \%$ & $0.00 \%$ & $0.00 \%$ & \multirow[b]{2}{*}{$\begin{array}{c}\text { Strongly } \\
\text { Agree }\end{array}$} & \multirow[b]{2}{*}{$\begin{array}{c}\text { Strongly } \\
\text { Agree }\end{array}$} \\
\hline & 7 & 4 & 4 & 0 & 0 & & \\
\hline \multirow{2}{*}{$\begin{array}{c}\text { During an international trip, my sustainability } \\
\text { education through IGERT affected my } \\
\text { perception of the environmental or social } \\
\text { sustainability of at least one place that was } \\
\text { visited. }\end{array}$} & $53.30 \%$ & $40 \%$ & $0.00 \%$ & $6.70 \%$ & $0.00 \%$ & \multirow[b]{2}{*}{$\begin{array}{c}\text { Strongly } \\
\text { Agree }\end{array}$} & \multirow[b]{2}{*}{$\begin{array}{c}\text { Strongly } \\
\text { Agree }\end{array}$} \\
\hline & 8 & 6 & 0 & 1 & 0 & & \\
\hline \multirow{3}{*}{$\begin{array}{l}\text { Compared to discussions without the CIA, the } \\
\text { discussion led by the CIA framework better } \\
\text { enabled me to identify my personal bias during a } \\
\text { trip abroad (India trip, Puerto Rico trip). }\end{array}$} & $40.00 \%$ & $40.00 \%$ & $20.00 \%$ & $0.00 \%$ & $0.00 \%$ & \multirow[b]{2}{*}{$\begin{array}{c}\text { Somewhat } \\
\text { Agree }\end{array}$} & \multirow[b]{2}{*}{$\begin{array}{c}\text { Strongly } \\
\text { Agree }\end{array}$} \\
\hline & 6 & 6 & 3 & 0 & 0 & & \\
\hline & $40.00 \%$ & $33.33 \%$ & $20.00 \%$ & $0.00 \%$ & $6.67 \%$ & & \\
\hline
\end{tabular}




\begin{tabular}{|c|c|c|c|c|c|c|c|}
\hline $\begin{array}{c}\text { Compared to other international trips where CIA } \\
\text { was not used (e.g. other educational trips, } \\
\text { personal trips, etc.), I was more aware of my } \\
\text { own bias when considering international } \\
\text { incidents because of my previous experience } \\
\text { with the CIA. }\end{array}$ & 6 & 5 & 3 & 0 & 1 & $\begin{array}{l}\text { Somewhat } \\
\text { Agree }\end{array}$ & $\begin{array}{l}\text { Strongly } \\
\text { Agree }\end{array}$ \\
\hline \multirow{2}{*}{$\begin{array}{c}\text { Compared to other experiences (including } \\
\text { domestic trips with immersion in another } \\
\text { culture) where CIA was not used, I was more } \\
\text { aware of my own bias because of my experience } \\
\text { with the CIA. }\end{array}$} & $33.30 \%$ & $40.00 \%$ & $20.00 \%$ & $6.67 \%$ & $0.00 \%$ & \multirow[b]{2}{*}{$\begin{array}{l}\text { Somewhat } \\
\text { Agree }\end{array}$} & \multirow[b]{2}{*}{$\begin{array}{l}\text { Somewhat } \\
\text { Agree }\end{array}$} \\
\hline & 5 & 6 & 3 & 1 & 0 & & \\
\hline \multirow{2}{*}{$\begin{array}{l}\text { My initial response to at least one critical } \\
\text { incident affected my ability to analyze the } \\
\text { incident from an unbiased perspective. }\end{array}$} & $26.70 \%$ & $26.70 \%$ & $33.33 \%$ & $13.33 \%$ & $0.00 \%$ & \multirow{2}{*}{$\begin{array}{l}\text { Somewhat } \\
\text { Agree }\end{array}$} & \multirow[b]{2}{*}{ Neutral } \\
\hline & 4 & 4 & 5 & 2 & 0 & & \\
\hline \multirow{2}{*}{$\begin{array}{l}\text { The CIA enhanced my ability to understand the } \\
\text { sustainability or sustainable practices of the } \\
\text { places and organizations visited during the } \\
\text { international trips }\end{array}$} & $53.90 \%$ & $46.20 \%$ & $0.00 \%$ & $0.00 \%$ & $0.00 \%$ & \multirow[b]{2}{*}{$\begin{array}{l}\text { Strongly } \\
\text { Agree }\end{array}$} & \multirow[b]{2}{*}{$\begin{array}{l}\text { Strongly } \\
\text { Agree }\end{array}$} \\
\hline & 7 & 6 & 0 & 0 & 0 & & \\
\hline \multirow{2}{*}{$\begin{array}{l}\text { The CIA helped me reflect deeply on at least } \\
\text { one critical incident }\end{array}$} & $76.90 \%$ & $7.80 \%$ & $15.40 \%$ & $0.00 \%$ & $0.00 \%$ & \multirow{2}{*}{$\begin{array}{l}\text { Strongly } \\
\text { Agree }\end{array}$} & \multirow{2}{*}{$\begin{array}{l}\text { Strongly } \\
\text { Agree }\end{array}$} \\
\hline & 10 & 1 & 2 & 0 & 0 & & \\
\hline \multirow{2}{*}{$\begin{array}{l}\text { The CIA helped me identify issues/incidents } \\
\text { where the group had conflicting perceptions. }\end{array}$} & $76.92 \%$ & $23.10 \%$ & $0.00 \%$ & $0.00 \%$ & $0.00 \%$ & \multirow{2}{*}{$\begin{array}{l}\text { Strongly } \\
\text { Agree }\end{array}$} & \multirow{2}{*}{$\begin{array}{l}\text { Strongly } \\
\text { Agree }\end{array}$} \\
\hline & 10 & 3 & 0 & 0 & 0 & & \\
\hline \multirow{2}{*}{$\begin{array}{l}\text { The CIA enabled me to ask questions/get } \\
\text { clarification about critical incidents }\end{array}$} & $69.23 \%$ & $30.77 \%$ & $0.00 \%$ & $0.00 \%$ & $0.00 \%$ & \multirow{2}{*}{$\begin{array}{l}\text { Strongly } \\
\text { Agree }\end{array}$} & \multirow{2}{*}{$\begin{array}{l}\text { Strongly } \\
\text { Agree }\end{array}$} \\
\hline & 9 & 4 & 0 & 0 & 0 & & \\
\hline
\end{tabular}




\begin{tabular}{|c|c|c|c|c|c|c|c|}
\hline \multirow{2}{*}{$\begin{array}{l}\text { The CIA made me aware of critical incidents I } \\
\text { may not have noticed }\end{array}$} & $76.90 \%$ & $23.10 \%$ & $0.00 \%$ & $0.00 \%$ & $0.00 \%$ & \multirow{2}{*}{$\begin{array}{l}\text { Strongly } \\
\text { Agree }\end{array}$} & \multirow{2}{*}{$\begin{array}{l}\text { Strongly } \\
\text { Agree }\end{array}$} \\
\hline & 10 & 3 & 0 & 0 & 0 & & \\
\hline \multirow{2}{*}{$\begin{array}{l}\text { The CIA allowed me to listen to my peers' } \\
\text { feelings and/or thoughts about a critical incident }\end{array}$} & $84.60 \%$ & $15.40 \%$ & $0.00 \%$ & $0.00 \%$ & $0.00 \%$ & \multirow{2}{*}{$\begin{array}{l}\text { Strongly } \\
\text { Agree }\end{array}$} & \multirow{2}{*}{$\begin{array}{l}\text { Strongly } \\
\text { Agree }\end{array}$} \\
\hline & 11 & 2 & 0 & 0 & 0 & & \\
\hline \multirow{2}{*}{$\begin{array}{l}\text { The CIA allowed me to express my feelings } \\
\text { and/or thoughts about a critical incident }\end{array}$} & $53.90 \%$ & $34.50 \%$ & $7.70 \%$ & $0.00 \%$ & $0.00 \%$ & \multirow{2}{*}{$\begin{array}{l}\text { Strongly } \\
\text { Agree }\end{array}$} & \multirow{2}{*}{$\begin{array}{l}\text { Strongly } \\
\text { Agree }\end{array}$} \\
\hline & 7 & 5 & 1 & 0 & 0 & & \\
\hline \multirow{2}{*}{$\begin{array}{l}\text { The CIA inspired further discussion after the } \\
\text { CIA was over (e.g. conversations in hotel rooms, } \\
\text { conversations with friends/family, etc.) }\end{array}$} & $61.50 \%$ & $30.70 \%$ & $7.70 \%$ & $0.00 \%$ & $0.00 \%$ & \multirow{2}{*}{$\begin{array}{l}\text { Strongly } \\
\text { Agree }\end{array}$} & \multirow{2}{*}{$\begin{array}{l}\text { Strongly } \\
\text { Agree }\end{array}$} \\
\hline & 8 & 4 & 1 & 0 & 0 & & \\
\hline \multirow{2}{*}{$\begin{array}{l}\text { On at least one occasion completing the CIA } \\
\text { changed my understanding of an incident. }\end{array}$} & $69.23 \%$ & $23.10 \%$ & $7.80 \%$ & $0.00 \%$ & $0.00 \%$ & \multirow{2}{*}{$\begin{array}{l}\text { Strongly } \\
\text { Agree }\end{array}$} & \multirow{2}{*}{$\begin{array}{l}\text { Strongly } \\
\text { Agree }\end{array}$} \\
\hline & 9 & 3 & 1 & 0 & 0 & & \\
\hline \multirow{2}{*}{$\begin{array}{l}\text { When a critical incident I suggested wasn't } \\
\text { chosen, I felt that my incident wasn't as } \\
\text { important as the one that was chosen. }\end{array}$} & $0.00 \%$ & $30.80 \%$ & $15.40 \%$ & $23.10 \%$ & $30.70 \%$ & \multirow{2}{*}{ Disagree } & \multirow{2}{*}{$\begin{array}{l}\text { Agree and } \\
\text { Strongly } \\
\text { Disagree }\end{array}$} \\
\hline & 0 & 4 & 2 & 3 & 4 & & \\
\hline \multirow{2}{*}{$\begin{array}{l}\text { I felt that I contributed equally to my peers when } \\
\text { conducting a CIA. }\end{array}$} & $23.10 \%$ & $30.77 \%$ & $30.77 \%$ & $15.40 \%$ & $0.00 \%$ & \multirow{2}{*}{$\begin{array}{l}\text { Somewhat } \\
\text { Agree }\end{array}$} & \multirow{2}{*}{$\begin{array}{l}\text { Somewhat } \\
\text { Agree and } \\
\text { Neutral }\end{array}$} \\
\hline & 3 & 4 & 4 & 2 & 0 & & \\
\hline \multirow{2}{*}{$\begin{array}{l}\text { I felt repetitive questions were necessary and/or } \\
\text { valuable to the CIA. }\end{array}$} & $15.40 \%$ & $15.40 \%$ & $15.40 \%$ & $53.90 \%$ & $0.00 \%$ & \multirow{2}{*}{ Disagree } & \multirow{2}{*}{ Disagree } \\
\hline & 2 & 2 & 2 & 7 & 0 & & \\
\hline \multirow{3}{*}{$\begin{array}{l}\text { The CIA helped me develop trust in the other } \\
\text { students during the trip. }\end{array}$} & $30.77 \%$ & $38.50 \%$ & $7.70 \%$ & $23.10 \%$ & $0.00 \%$ & \multirow{2}{*}{$\begin{array}{l}\text { Somewhat } \\
\text { Agree }\end{array}$} & \multirow{2}{*}{$\begin{array}{l}\text { Somewhat } \\
\text { Agree }\end{array}$} \\
\hline & 4 & 5 & 1 & 3 & 0 & & \\
\hline & $23.00 \%$ & $46.20 \%$ & $15.40 \%$ & $15.40 \%$ & $0.00 \%$ & & \\
\hline
\end{tabular}


The location (hotel lobby or patio, beach, bus, etc.) of the CIA strongly influenced how much I participated

I felt that the CIA was successful whether done
in a dark or light space

\begin{tabular}{|c|c|c|c|c|c|c|}
\hline 3 & 6 & 2 & 2 & 0 & $\begin{array}{c}\text { Somewhat } \\
\text { Agree }\end{array}$ & $\begin{array}{c}\text { Somewhat } \\
\text { Agree }\end{array}$ \\
\hline $30.77 \%$ & $23.10 \%$ & $23.10 \%$ & $15.40 \%$ & $7.70 \%$ & \multirow{2}{*}{$\begin{array}{c}\text { Somewhat } \\
\text { Agree }\end{array}$} & \multirow{2}{*}{$\begin{array}{c}\text { Strongly } \\
\text { Agree }\end{array}$} \\
\hline 4 & 3 & 3 & 2 & 1 & & \\
\hline $50.00 \%$ & $41.70 \%$ & $8.33 \%$ & $0.00 \%$ & $0.00 \%$ & \multirow{2}{*}{$\begin{array}{c}\text { Strongly } \\
\text { Agree and } \\
\text { Somewhat } \\
\text { Agree }\end{array}$} & \multirow{2}{*}{$\begin{array}{c}\text { Strongly } \\
\text { Agree }\end{array}$} \\
\hline 6 & 5 & 1 & 0 & 0 & & \\
\hline $0.00 \%$ & $7.70 \%$ & $23.10 \%$ & $46.20 \%$ & $23.10 \%$ & \multirow{2}{*}{ Disagree } & \multirow{2}{*}{ Disagree } \\
\hline 0 & 1 & 3 & 6 & 3 & & \\
\hline $30.77 \%$ & $23.10 \%$ & $30.77 \%$ & $7.70 \%$ & $7.70 \%$ & \multirow{2}{*}{$\begin{array}{c}\text { Somewhat } \\
\text { Agree }\end{array}$} & \multirow{2}{*}{$\begin{array}{c}\text { Strongly } \\
\text { Agree and } \\
\text { Neutral }\end{array}$} \\
\hline 4 & 3 & 4 & 1 & 1 & & \\
\hline $0.00 \%$ & $40.00 \%$ & $20.00 \%$ & $20.00 \%$ & $20.00 \%$ & \multirow{2}{*}{ Neutral } & \multirow{2}{*}{$\begin{array}{c}\text { Somewhat } \\
\text { Agree }\end{array}$} \\
\hline 0 & 2 & 1 & 1 & 1 & & \\
\hline $46.20 \%$ & $23.10 \%$ & $23.10 \%$ & $7.70 \%$ & $0.00 \%$ & \multirow{2}{*}{$\begin{array}{c}\text { Somewhat } \\
\text { Agree }\end{array}$} & \multirow{2}{*}{$\begin{array}{c}\text { Strongly } \\
\text { Agree }\end{array}$} \\
\hline 6 & 3 & 3 & 1 & 0 & & \\
\hline $53.90 \%$ & $38.50 \%$ & $7.70 \%$ & $0.00 \%$ & $0.00 \%$ & \multirow{2}{*}{$\begin{array}{c}\text { Strongly } \\
\text { Agree }\end{array}$} & \multirow{2}{*}{$\begin{array}{c}\text { Strongly } \\
\text { Agree }\end{array}$} \\
\hline 7 & 5 & 1 & 0 & 0 & & \\
\hline
\end{tabular}

I participated more when the CIA was conducted in a circle than when we were sitting in rows (e.g. on a bus)

I felt comfortable participating in the CIAs when strangers could possibly overhear

I felt the level of background noise affected my
level of participation in the CIA

How often did you feel motion sickness affected your level of participation in a CIA when in a

\begin{tabular}{c} 
moving vehicle? \\
\hline The time of day influenced my desire to \\
participate in the CIA.
\end{tabular}

When the group had different thoughts about, opinions of, and experiences with an event, I was interested in participating in the discussion. 


\begin{tabular}{|c|c|c|c|c|c|c|c|}
\hline \multirow{2}{*}{$\begin{array}{l}\text { When the group largely shared the same } \\
\text { thoughts about, opinions of, and experiences } \\
\text { with an event, I was interested in participating in } \\
\text { the discussion. }\end{array}$} & $30.77 \%$ & $15.40 \%$ & $30.77 \%$ & $23.10 \%$ & $0.00 \%$ & \multirow[b]{2}{*}{ Neutral } & \multirow{2}{*}{$\begin{array}{l}\text { Strongly } \\
\text { Agree and } \\
\text { Neutral }\end{array}$} \\
\hline & 4 & 2 & 4 & 3 & 0 & & \\
\hline \multirow{2}{*}{$\begin{array}{l}\text { When the CIA was first introduced, I felt that it } \\
\text { would be a useful tool for understanding } \\
\text { sustainability in an international context }\end{array}$} & $7.70 \%$ & $61.54 \%$ & $23.10 \%$ & $7.70 \%$ & $0.00 \%$ & \multirow{2}{*}{$\begin{array}{l}\text { Somewhat } \\
\text { Agree }\end{array}$} & \multirow{2}{*}{$\begin{array}{l}\text { Somewhat } \\
\text { Agree }\end{array}$} \\
\hline & 1 & 8 & 3 & 1 & 0 & & \\
\hline \multirow{2}{*}{$\begin{array}{c}\text { When the CIA was first introduced, I felt that it } \\
\text { would be a useful tool for supporting group } \\
\text { discussions }\end{array}$} & $38.50 \%$ & $23.10 \%$ & $15.40 \%$ & $15.40 \%$ & $7.70 \%$ & \multirow{2}{*}{$\begin{array}{l}\text { Somewhat } \\
\text { Agree }\end{array}$} & \multirow{2}{*}{$\begin{array}{l}\text { Strongly } \\
\text { Agree }\end{array}$} \\
\hline & 5 & 3 & 2 & 2 & 1 & & \\
\hline \multirow{2}{*}{$\begin{array}{l}\text { When the CIA was first introduced, I felt that it } \\
\text { would be a useful tool for } \\
\text { recording/documenting the trip experiences }\end{array}$} & $30.70 \%$ & $61.50 \%$ & $7.70 \%$ & $0.00 \%$ & $0.00 \%$ & \multirow{2}{*}{$\begin{array}{l}\text { Somewhat } \\
\text { Agree }\end{array}$} & \multirow{2}{*}{$\begin{array}{l}\text { Somewhat } \\
\text { Agree }\end{array}$} \\
\hline & 4 & 8 & 1 & 0 & 0 & & \\
\hline \multirow{2}{*}{$\begin{array}{l}\text { When the CIA was first introduced, I felt that it } \\
\text { would be a useful tool for increasing my cultural } \\
\text { awareness }\end{array}$} & $7.70 \%$ & $30.77 \%$ & $38.50 \%$ & $15.40 \%$ & $7.70 \%$ & \multirow{2}{*}{ Neutral } & \multirow{2}{*}{ Neutral } \\
\hline & 1 & 4 & 5 & 2 & 1 & & \\
\hline \multirow{2}{*}{$\begin{array}{l}\text { After the international trips, I felt the CIA was a } \\
\text { useful tool for understanding sustainability in an } \\
\text { international context }\end{array}$} & $38.50 \%$ & $46.15 \%$ & $7.70 \%$ & $7.70 \%$ & $0.00 \%$ & \multirow{2}{*}{$\begin{array}{l}\text { Somewhat } \\
\text { Agree }\end{array}$} & \multirow{2}{*}{$\begin{array}{l}\text { Somewhat } \\
\text { Agree }\end{array}$} \\
\hline & 5 & 6 & 1 & 1 & 0 & & \\
\hline \multirow{2}{*}{$\begin{array}{l}\text { After the international trips, I felt the CIA was a } \\
\text { useful tool for supporting group discussions }\end{array}$} & 84.6 & $15.40 \%$ & $0.00 \%$ & $0.00 \%$ & $0.00 \%$ & \multirow{2}{*}{$\begin{array}{l}\text { Strongly } \\
\text { Agree }\end{array}$} & \multirow{2}{*}{$\begin{array}{l}\text { Strongly } \\
\text { Agree }\end{array}$} \\
\hline & 11 & 2 & 0 & 0 & 0 & & \\
\hline \multirow{2}{*}{$\begin{array}{l}\text { After the international trips, I felt the CIA was a } \\
\text { useful tool for recording/documenting the trip } \\
\text { experiences }\end{array}$} & $61.50 \%$ & $30.70 \%$ & $7.70 \%$ & $0.00 \%$ & $0.00 \%$ & \multirow{2}{*}{$\begin{array}{l}\text { Strongly } \\
\text { Agree }\end{array}$} & \multirow{2}{*}{$\begin{array}{l}\text { Strongly } \\
\text { Agree }\end{array}$} \\
\hline & 8 & 4 & 1 & 0 & 0 & & \\
\hline
\end{tabular}




\begin{tabular}{|c|c|c|c|c|c|c|c|}
\hline \multirow{2}{*}{$\begin{array}{l}\text { After the international trips, I felt the CIA was a } \\
\text { useful tool for increasing my cultural awareness }\end{array}$} & $69.23 \%$ & $23.10 \%$ & $7.70 \%$ & $0.00 \%$ & $0.00 \%$ & \multirow{2}{*}{$\begin{array}{l}\text { Strongly } \\
\text { Agree }\end{array}$} & \multirow{2}{*}{$\begin{array}{l}\text { Strongly } \\
\text { Agree }\end{array}$} \\
\hline & 9 & 3 & 1 & 0 & 0 & & \\
\hline Question Text & True & False & & & & Median & Mode \\
\hline \multirow{2}{*}{$\begin{array}{l}\text { Did you find any practices during the India trip } \\
\text { to be more or less sustainable when viewed } \\
\text { through the lens of a North American measure } \\
\text { of sustainability? }\end{array}$} & 12 & 2 & & & & \multirow[b]{2}{*}{ True } & \multirow[b]{2}{*}{ True } \\
\hline & $85.70 \%$ & $14.30 \%$ & & & & & \\
\hline \multirow{2}{*}{$\begin{array}{l}\text { Do you get motion sickness when writing or } \\
\text { reading in a moving vehicle }\end{array}$} & $42.90 \%$ & $57.20 \%$ & & & & \multirow{2}{*}{ False } & \multirow{2}{*}{ False } \\
\hline & 6 & 8 & & & & & \\
\hline \multirow{2}{*}{$\begin{array}{l}\text { Do you get motion sickness when writing or } \\
\text { reading in a moving vehicle }\end{array}$} & $42.90 \%$ & $57.20 \%$ & & & & \multirow{2}{*}{ False } & \multirow{2}{*}{ False } \\
\hline & 6 & 8 & & & & & \\
\hline Question Text & $\begin{array}{l}\text { Extremel } \\
y \\
\text { Comforta } \\
\text { ble }\end{array}$ & $\begin{array}{l}\text { Somewha } \\
\mathbf{t} \\
\text { Comforta } \\
\text { ble }\end{array}$ & $\begin{array}{c}\text { Neither } \\
\text { Comforta } \\
\text { ble Nor } \\
\text { Uncomfo } \\
\text { rtable }\end{array}$ & $\begin{array}{c}\text { Somewha } \\
\mathbf{t} \\
\text { Uncomfo } \\
\text { rtable }\end{array}$ & $\begin{array}{l}\text { Extremel } \\
\quad y \\
\text { Uncomfo } \\
\text { rtable }\end{array}$ & Median & Mode \\
\hline \multirow{2}{*}{$\begin{array}{c}\text { I was ___ sharing my ideas and thoughts with } \\
\text { the group. }\end{array}$} & $7.80 \%$ & $76.90 \%$ & $15.40 \%$ & $0.00 \%$ & $0.00 \%$ & \multirow{2}{*}{$\begin{array}{c}\text { Somewhat } \\
\text { Comfortabl } \\
\text { e }\end{array}$} & \multirow{2}{*}{$\begin{array}{l}\text { Somewhat } \\
\text { Comfortable }\end{array}$} \\
\hline & 1 & 10 & 2 & 0 & 0 & & \\
\hline \multirow{2}{*}{$\begin{array}{c}\text { I felt ___ conducting the CIA when faculty } \\
\text { were present. }\end{array}$} & $15.40 \%$ & $46.20 \%$ & $23.10 \%$ & $15.40 \%$ & $0.00 \%$ & \multirow{2}{*}{$\begin{array}{c}\text { Somewhat } \\
\text { Comfortabl } \\
\text { e }\end{array}$} & \multirow{2}{*}{$\begin{array}{l}\text { Somewhat } \\
\text { Comfortable }\end{array}$} \\
\hline & 2 & 6 & 3 & 2 & 0 & & \\
\hline
\end{tabular}




\begin{tabular}{|c|c|c|c|c|c|c|c|}
\hline Question Text & $\begin{array}{l}\text { Less than } \\
30 \\
\text { Minutes }\end{array}$ & $\begin{array}{c}\text { 30-60 } \\
\text { Minutes }\end{array}$ & $\begin{array}{c}61-90 \\
\text { Minutes }\end{array}$ & $\begin{array}{c}\text { More } \\
\text { than } 90 \\
\text { Minutes }\end{array}$ & Other & Median & Mode \\
\hline \multirow{2}{*}{$\begin{array}{l}\text { What was the ideal amount of time to dedicate } \\
\text { to the CIA? }\end{array}$} & $7.70 \%$ & $84.60 \%$ & $7.70 \%$ & $0.00 \%$ & $0.00 \%$ & \multirow{2}{*}{$\begin{array}{l}\text { 30-60 } \\
\text { Minutes }\end{array}$} & \multirow{2}{*}{$\begin{array}{c}30-60 \\
\text { Minutes }\end{array}$} \\
\hline & 1 & 11 & 1 & 0 & 0 & & \\
\hline Question Text & $\begin{array}{l}\text { Less than } \\
5 \text { People }\end{array}$ & $\begin{array}{c}5-10 \\
\text { People }\end{array}$ & $\begin{array}{c}\text { 11-15 } \\
\text { People }\end{array}$ & $\begin{array}{c}\text { More } \\
\text { than } 15 \\
\text { People }\end{array}$ & Other & Median & Mode \\
\hline \multirow{2}{*}{$\begin{array}{l}\text { What do you believe was the ideal group size for } \\
\text { the CIA? }\end{array}$} & $7.70 \%$ & $69.20 \%$ & $23.10 \%$ & $0.00 \%$ & $0.00 \%$ & \multirow{2}{*}{ 5-10 People } & \multirow{2}{*}{ 5-10 People } \\
\hline & 1 & 9 & 3 & 0 & 0 & & \\
\hline Question Text & Morning & $\begin{array}{l}\text { Afternoo } \\
\mathbf{n}\end{array}$ & Evening & $\begin{array}{l}\text { Late } \\
\text { Night }\end{array}$ & & Median & Mode \\
\hline \multirow{2}{*}{$\begin{array}{l}\text { What was the time of day you were most willing } \\
\text { to participate in the CIA }\end{array}$} & $36.36 \%$ & $18.18 \%$ & $36.36 \%$ & $9.09 \%$ & & \multirow{2}{*}{ Afternoon } & \multirow{2}{*}{$\begin{array}{l}\text { Morning } \\
\text { and Evening }\end{array}$} \\
\hline & 4 & 2 & 4 & 1 & & & \\
\hline \multirow{2}{*}{$\begin{array}{l}\text { What was the second best time of day for you to } \\
\text { participate in the CIA }\end{array}$} & $9.09 \%$ & $72.73 \%$ & $18.18 \%$ & $0.00 \%$ & & \multirow{2}{*}{ Afternoon } & \multirow{2}{*}{ Afternoon } \\
\hline & 1 & 8 & 2 & 0 & & & \\
\hline \multirow{2}{*}{$\begin{array}{l}\text { / What was the third best time of day for you to } \\
\text { participate in the CIA }\end{array}$} & $12.50 \%$ & $12.50 \%$ & $37.50 \%$ & $37.50 \%$ & & \multirow{2}{*}{ Evening } & \multirow{2}{*}{$\begin{array}{l}\text { Evening and } \\
\text { Late Night }\end{array}$} \\
\hline & 1 & 1 & 3 & 3 & & & \\
\hline \multirow{2}{*}{$\begin{array}{l}\text { What was the worst of day you for you to } \\
\text { participate in the CIA }\end{array}$} & $50.00 \%$ & $0.00 \%$ & $0.00 \%$ & $50.00 \%$ & & \multirow{2}{*}{$\begin{array}{c}\text { Morning } \\
\text { and Late } \\
\text { Night }\end{array}$} & \multirow{2}{*}{$\begin{array}{c}\text { Morning } \\
\text { and Late } \\
\text { Night }\end{array}$} \\
\hline & 4 & 0 & 0 & 4 & & & \\
\hline
\end{tabular}

